\title{
SERGE ALEXANDER KORFF
}

1906-1989

Serge Alexander Korff, Professor Emeritus of Physics at New York University and a pioneer in the study of cosmic rays, died in New York City on December 1, 1989 at the age of 83. His early research paved the way that led in 1949 to W F Libby's elaboration of the technique of ${ }^{14} \mathrm{C}$ dating, along with his collaborators, E C Anderson and J R Arnold, at the University of Chicago.

Beginning in the early 1930s, Dr Korff studied the streams of particles reaching the upper atmosphere from outer space, working with teams directed by the distinguished physicists, R A Millikan and A H Compton. This was before the days of high-altitude jet aircraft and satellites, when rocketry was in its infancy, and cosmic radiation was measured with instruments sent aloft by balloons or with heavy equipment placed at a few high-altitude stations in different parts of the earth.

From these studies, it was discovered that the charged particles of cosmic rays, arriving from far out in our galaxy and consisting mostly of protons, become sorted by the earth's magnetic field. Their intensity was found to vary with latitude and as a function of altitude, increasing at high altitude from the equator to about $60^{\circ} \mathrm{N}$.

The impact of Dr Korff's work on Earth Sciences became apparent to Libby in 1940 when Korff, together with H A Bethe and G Placzek, realized that cosmic-ray-induced secondary neutrons react in the upper atmosphere with ${ }^{14} \mathrm{~N}$ nuclei to produce ${ }^{14} \mathrm{C}$. This discovery, acknowledged by W F Libby in his Nobel address in 1960, was critical in setting the stage for 1) tracing the pathway along which ${ }^{14} \mathrm{C}$ at equilibrium cycled in the biosphere by photosynthesis and respiration in living autotrophic plants, and 2) ascertaining from the half-life of ${ }^{14} \mathrm{C}$ and the specific activity of sample material, the ages of ancient plant and animal remains.

Serge Alexander Korff, born in 1906 in Helsingfors (now Helsinki), Finland, came from a family of Russian statesmen and academics. His formal university education, following the family's emigration to the United States, was at Princeton (A B 1927, A M 1929, Ph D 1931). Later, he held research positions at Mount Wilson Observatory, California Institute of Technology, Carnegie Institution of Washington and Bartol Research Foundation, before joining the faculty of New York University in 1940, advancing in rank to Professor of Physics in 1946, and remaining there until his retirement in 1973.

Dr Korff possessed the bearing of a statesman, diplomat and scholar, all of which developed naturally from his family background. His demeanor was one of polished authority and leadership, which qualities were to great advantage during times of service to the institutions he served as President, including the American Geographical Society (1967-1971), New York Academy of Sciences (1972), and the Explorers Club (1955-1958). At the same time, as a world traveler, he projected his zeal for research by the number of high-altitude stations he helped to establish, especially during the International Geophysical Year (1957-1958) at far-flung places exemplified by Chacaltaya $(5220 \mathrm{~m})$ in Bolivia, Mt Wrangell $(4269 \mathrm{~m})$ in Alaska and Norikura-dake $(2840 \mathrm{~m})$ in Japan.

Dr Korff's career was in every sense a distinguished one, pursued with dedication to achieve in research, education and, above all, the understanding of earth phenomena.

C J Heusser

\section{SELECTED BIBLIOGRAPHY}

Bethe, HA, Korff, SA, Placzek, G 1940 On the interpretation of neutron measurements in cosmic radiation. Phys Rev 57:573-587.

Bowen, IS, Millikan, RA, Korff, SA and Neher, HV 1936 The latitude effect in cosmic rays at altitudes up to 29,000 feet. Phys Rev 50:579-581.

Korff, SA 1956 The effect of cosmic rays on the terrestrial isotope distribution. Proc New York Acad Sci 67:35-54.

1960 Geographical aspects of cosmic-ray studies. Geogr Rev 50:504-522.

Korff, SA and Mendell, RB 1980 Variations in radiocarbon production in the earth's atmosphere. In Stuiver, M and Kra, RS, eds, Internatl ${ }^{14} \mathrm{C}$ conf, 10th, Proc. Radiocarbon 22(2):159-165.

Libby, WF 1946 Atmospheric helium three and radiocarbon from cosmic radiation. Phys Rev 69:671-672.

— 1952 Radiocarbon dating. Chicago, Univ Chicago Press. 1961 Radiocarbon dating. Science 133:621-629. 